\title{
THE EFFECTIVENESS AND THE PROBLEMS FACED IN THE TEACHING AND LEARNING OF THE ENGLISH LANGUAGE IN A SPECIAL EDUCATION CLASSROOM IN MALAYSIA
}

\author{
Gunasegaran Karuppannan ${ }^{11}$, \\ Muhantha Paramalingam², \\ Fazal Mohamed Mohamed Sultan ${ }^{3}$, \\ Hatnin Duari ${ }^{4}$ \\ ${ }^{1}$ Assoc. Prof. Dr., \\ Deputy Dean, Centre for Graduate Studies, \\ Universiti Selangor, \\ Malaysia \\ orcid.org/0000-0002-9471-7883 \\ ${ }^{2}$ Lecturer, \\ Lincoln University College, \\ Petaling Jaya, \\ Malaysia \\ ${ }^{3}$ Assoc. Prof. Dr., \\ Head of Applied Linguistics Research Cluster, \\ Faculty of Social Science and Humanities, \\ Universiti Kebangsaan Malaysia, \\ Malaysia \\ orcid.org/0000-0002-2910-014X \\ ${ }^{4}$ Academic Teacher, \\ Tandek Kota Marudu Secondary School, \\ Sabah, Malaysia
}

\begin{abstract}
:
This qualitative case study investigated the effectiveness of lesson delivery and sequence of content and learning expectations of two English Language attached to a special education (Integration programme) school in Petaling Jaya. Malaysia. It also focused on the teaching and learning problems encountered in the particular classrooms. This study brings broader understanding of strategies for effective teaching of English in a special education classroom in Malaysia. The rationale for the study stems from the need to gain greater perspective of the teaching of English learners in a special education classroom. Results reflect analysis of classroom observation, face to face interview with two English Language and document review. Emerging from the data are some effective teaching strategies and profound problems that special education English Language teachers can add to their repertoire.
\end{abstract}

i Correspondence: email drguna@unisel.edu.my 
Keywords: qualitative, expectations, strategies, classroom observation, interview

\section{Introduction}

In Malaysia, students with special education needs include students with visual impairment, hearing impairment, hearing impairment, speech difficulties, physical disabilities, multiple disabilities and learning disabilities such as autism, Down's Syndrome, attention deficit hyperactivity disorders and dyslexia (Gunasegaran et al., 2021). Special Education Integration Programme (SEIP) which is a mainstream school with specific classes dedicated to special education needs students.

The Kurikulum Standard Sekolah Rendah Pendidikan Khas, which is KSSR Special Education (Learning Disabilities) was constructed to be consistent with the National Education Philosophy, to fulfil individuals' needs, the teaching and learning processes in learning disabilities programme is designed to be flexible and aligned with the 1977 Special Education Regulations that stated "teachers are able to modify the methods or the techniques of teaching and learning, time and structure for the activity, the subject and the teaching aids in order to achieve the objectives and goals of Special Education" (Datu Masjidin \& Gunasegaran, 2020). The degree of flexibility within the curriculum allows adaptation to the specific requirements of special education needs children.

Language and communication disorders are common among children with school and social learning problems. These children are called learning disabled, slow learners, learning handicapped or language disabled. Whatever the label, these children are of concern, partially because the ability to use language is so critical in acquiring academic skills (Ketheeswaran, 2021).

The English as a second language programme for Special Education is planned according to the ability and achievement of each individual. A syllabus is designed for the Special Education students with learning difficulties. The English Language Syllabus for the Special Education Programme aims to enable pupils to communicate orally and in writing in and out of school.

By the end of primary education, students should be able to achieve the following:

1) listen, imitate and understand simple spoken English,

2) speak and respond clearly in different situations,

3) read and understand simple messages, and

4) write simple information using simple language

\section{Statement of Problem}

English Language teachers in a special education classroom have greater responsibilities and demands as they have to decide on different instructional techniques in the form of accommodation where a reasonable adjustment needs to be made to teaching practices so that is more accessible to the pupils, or in the form modification of materials through changes and adaptations to make it simpler. The class population comprises of different 
types of learning difficulties and the need to cater for individual child would be a challenging task.

\subsection{Objectives}

1) To identify the suitability of instructional materials used by the teacher.

2) To identify the instructional strategies used by the teacher.

3) To identify the teaching and learning problems encountered in the classroom.

\section{Literature Review}

Language is a code that we learn to use in order to communicate ideas and express our wants and needs. Reading, writing, speaking and some gesture systems are all forms of language as described by the American-Speech- Language- Hearing Association (ASHA), (1991). English language subject focusses on encompasses skills such as: listening, repeating and understanding simple spoken language, speaking and responding appropriately according to situations, to read and understand simple messages, to write down given information in simple sentences; and to use language skills in daily life.

The teaching module based on the Special Education Curriculum KSSR (2003), helps teachers implement effective and efficient teaching. Teachers have the flexibility to change, improvise or built more effective teaching plans in accordance with the needs of the pupils. Active involvement of the pupils would help increase pupils' performance. In implementing teaching and learning English Language, teachers are able to diversify approaches in order to attain the objectives of the Teaching and Learning Standard stated in the curriculum.

Virginia Collier's Conceptual Model for Acquiring a Second Language (1995) helps explain the complex interacting factors that pupils experience when acquiring a second language. The Model has four major components: sociocultural, linguistic, academic and cognitive process.

Sometimes characteristics of typical English Language learners look similar to the learning difficulties experienced by students with special education needs . It is necessary to gain more information and go through a systematic and focused process to determine the root of each pupils' difficulties, and the most appropriate and effective method to address his or her needs.

Pupils' difficulties in learning languages explained through a Special Education lens as stated by Hamayan, are:

1) Difficulty in reading and spelling words- memory problems; phonological processing deficits; difficulties reading at the word-level (i.e. dyslexia);

2) Difficulty in comprehending text- language processing problems, sequencing problems, memory problems;

3) Poor writing skills- processing problems, memory problems, fine motor skills, slow processing speed, difficulty developing language skills; 
4) Easily distracted-auditory processing difficulty, attention problems, including ADHD, processing speed difficulty;

5) Unable to remember information taught- memory problem, language processing problem;

6) Adds, deletes or replaces words, paraphrases when speaking- memory or oral language processing difficulties, word finding difficulties.

\section{Methodology}

The methodology here presents the profile of the class involved in this qualitative case study; the interview carried out with the teachers; observation of the teaching and learning of the English Language Year 4 class.

The research site was at Taman Medan Secondary School in Petaling Jaya, Malaysia. There is a special education integration program in this school. It has a student population of 94. The ethnic composition of the students are: 88 Malays and 6 Indians. There is a total of 9 classes of Level 1 and 2 with a teaching staff of 6 . Three of them are English Language teachers with relevant qualifications.

\subsection{Procedures of Data Collection}

Data was collected through observation, and interviews with two English Language teachers. Interviews were carried out prior to the classroom observation. Interviews followed a semi- structured format that provided a conversational tone but stayed focused on the research questions. The classroom observation provided descriptive data.

\subsection{Observation Protocol}

Teacher's instructions to the students were focused. Pupils' responses were noted to analyse student behavior and learning. In addition to the teachers' instructions, notice was also made of the instructional materials used.

\subsection{Interview Protocol}

The interview protocol was constructed with 10 questions. The questions were designed to learn about the teaching strategies and the common problems they encounter in the teaching and learning of the English Language. Open ended questions that allowed the teachers to elaborate on the strategies and the problems they encounter.

\subsection{Document Review}

The Special Education Curriculum for Learning Disabilities English Language Year 4, Syllabus for Year 4 and Scheme of Work for Year 4 was used. 


\section{Analysis of Data}

The Year 4 class had 11 pupils of varying disabilities out of which 8 were boys and 3 girls. 5 boys and 1 girl have low Intelligent Quotient, 1 boy with dyslexia, 1 girl with autism, 1 boy with ADHD, 1 boy with learning problem and another as slow learner and 1 girl with physical disability.

The lesson was a 60 minute follow- up lesson on the topic "Tame and Wild Animals". The content Standard is to recognize animals and the learning Standard is to be able to name and differentiate tame animals from wild animals. Five types of wild animals and five type of tame animals were used. The success criteria set for the lesson was the use of pictures to say the names of the animals. The main activity for the lesson was oral drilling where the pupils say after the teacher the names of five tame and five wild animals. Pupils were asked to name the animals as a Look and Say exercise, and group them according to tame and wild categories. Colourful picture cards were used for the activity which led to a matching activity in a form of a game where the pupils match pictures of animals with words and finally categorize. This was consolidation activity. Peer coaching by a pupil was evident. The problems faced by the teacher is the poor memory skill of the pupils. The needs to initiate the pupils through a recall code that is by certain gestures that can trigger the memory of pupils. The teacher needs about two to three weeks to complete a topic due to the poor memory skill of most pupils in the class, absenteeism of pupils contributes to this problem of poor memory as the pupils are unable to follow the lesson consistently. In addition, bilingual instructions from English to Bahasa Melayu has to be used for understanding and active participation of pupils. The pupils tend to remain silent and not focused if no translation is done by the teacher. Generally, the pupils answer in Bahasa Melayu for the questions asked in English due to poor memory skill. the pupils appear to be silent during the reading skill .

\section{Conclusion}

The instructional materials used for the lesson was appropriate. The teacher has selected pictures that depict the actual colours of the tame and wild animals. The word cards were clear, and pupils could have read the words well if not for poor word recognition. A poster on animals in the lesson classroom was able to capture the attention of the pupils. The teacher had adapted and accommodated materials well.

The teacher initiates the pupils in assisting them to recall the previous lessons on the topic. The Look and Say strategy is apt for the students to recall. The oral drilling as the pupils repetitively say after the teacher can enhance the pupils' memory skill. Matching of words with picture leads to spelling and writing. Playing games related to the topic is an effective reinforcement for the topic. Categorizing the wild and tame animals is to develop the processing skill.

The teacher has 28 years of teaching experience. The teacher allows the students to work at their own pace and repeats the topic for the week. The pupils use of Bahasa 
Melayu is due to the environment the pupils come from. Patience is the key word as the teacher says. The teacher adapts and simplifies workbooks and materials in the textbook specifically the class. The pupils enjoy the games carried out in the class and it makes active participation of the pupils.

\section{Conflict of Interest Statement}

The authors declare no conflicts of interests.

\section{About the Authors}

Gunasegaran Karuppannan is an Associate Professor at Universiti Selangor (UNISEL) situated in Malaysia. Currently he holds the post as Deputy Dean in Centre for Graduate Studies office. He received his Bachelor Degree (Hons in Genetics) from Universiti Kebangsaan Malaysia (UKM), then he continued his study at University Malaya to get his Masters degree in Educational Management. Finally, he received his PhD from Universiti Putra Malaysia (UPM) in 2004 on Educational Administration focussing on Special Education. His major research interests are the area of Special Education. He is an active researcher who has participated in various international conferences as conference chairperson, keynote speaker or normal presenter and has published articles in a number of journals. Associate Professor Dr Gunasegaran Karuppannan is also the Associate Secretary for Malaysia in the Asia Pacific School Psychology Association. Also, member in Malaysian School Psychology Association and in Malaysian Psychology Association. Through-out his career, he had involved either as leader or member in a few research projects mainly focussing on special education. He has also written two books on special education.

Fazal Mohamed Mohamed Sultan is an Associate Professor at Universiti Kebangsaan Malaysia (UKM), situated in Malaysia. First, he received his Bachelor Degree (Hons) from California State University, Fresno, USA, then he continued his study at the University of Delaware, Newark, USA, to get his Masters degree in Formal Linguistics. Finally, he received his PhD from Universiti Kebangsaan Malaysia (UKM) in 2006 on Linguistics, focussing on Malay Linguistics. He is a linguistics lecturer in the Linguistics Program at the Research Center for Language and Linguistics at UKM for 14 years. He had been the Head of the Linguistics Program. Currently, he holds the post as Head of Applied Linguistics Research Cluster at the Research Center for Language and Linguistics, Faculty of Social Science and Humanities. His primary research interests are the area of syntax, GIS, Orang Asli education and language. He is an active researcher who has participated in various international conferences as conference chairperson, keynote speaker or regular presenter and has published articles in several journals.

Dr. Muhantha Paramalingam graduated from University of Strathclyde, Glasgow, Scotland with a B.A. Hons (TESOL) degree. She obtained her Masters in ESL (MESL) degree in 2002 from University of Malaya (UM). In 2019, she graduated from University of Selangor (UNISEL) with a Doctorate in Education (EdD). In addition, she posseses basic and specialist professional qualifications in TESL from Maktab Perguruan Raja 
Melewar, Seremban and Maktab Perguruan Lembah Pantai, Kuala Lumpur , respectively. Dr Muhantha has served as an English Language teacher in both primary and secondary schools under the Ministry of Education before her compulsory retirement in 2019, she was a MUET; and Literature in English.

Dr. Hatnin B. Duari obtained his B.Edu. in Malay Studies from Universiti Malaya (UM) in 1999, graduated M.A in Education Management from Universiti Selangor (UNISEL) in 2008, and Ed.D from Universiti Selangor (UNISEL) in 2018. He is a Part -Time Tutor of the Department of Education, Pengajian Jarak Jauh (PJJ) Universiti Putra Malaysia (UPM) for 10 years. He used to be the Jurulatih Utama (JU) of the Kota Marudu Sabah District Action Research. Currently, he is the Head of the Form 6 Pengajian Am Unit at SMK Tandek Kota Marudu Sabah. Her research interests are focused on Teaching and Learning in schools. Dr. Hatnin is currently a member of the Malaysian Psychological Association (PSIMA).

\section{References}

American Speech-Language-Hearing Association. (1991). State Speech- Language Pathology and Audiology Regulatory Agencies.

Collier, V. F. (1995). Acquiring a Second Language for school: Directions in Language and Education. National Clearinghouse for Bilingual Education, Vol 1 (4), 4-16. https://eric.ed.gov/?id=ED394301

Cummins P. (1994). Knowledge, power and identity in teaching English as a second language. In F. Genesee (Ed), "Educating the whole community" (pp-103-25). Cambridge, England: Cambridge University Press. http://esl.fis.edu/teachers/support/cummin.htm

Datu Masjidin Datu Moksan \& Gunasegaran Karuppannan (2020). Inclusive Programmes in Malaysia: Mainstream School Teachers' Acceptance Towards Special Education Students.

International Journal of Humanities and Education Research. Volume 2, Issue 2, 2020 (Page 1 - 8). http://www.humanitiesjournal.net/article/view/22/2-2-16

Dokumen Standard Kurikulum dan Pentaksiran Bahasa Inggeris: Masalah Pembelajaran Tahun Empat. Kementerian Pendidikan Malaysia, 2013.

Gunasegaran Karuppannan, Angela Chan Nguk Fong, Fazal Muhamad and Datu Masjidin Moksan (2021). Awareness of Tourette Syndrome in Malaysia. European Journal of Humanities and Social Sciences. Volume 1 No (4). Page 29 - 32. https://doi.org/10.24018/ejsocial.2021.1.4.91

Hamayan, E., Marler. Sanchoz, C, and Darmino, J. Special Education Considerations for English Language learners: Delivering a Continuum of Services, Calson Publishing, 2003. 
Ketheeswaran K. (2021). Supporting The Special Education Unit System in Promoting Inclusive Education. European Journal of Special Education Research. Vol 7 (3). Page 17-34. DOI: 10.46827/ejse.v7i3.3869

Lay Wah Lee \& Hui Min Low. (2014). The evolution of special education in Malaysia. Nasen British Journal of Special Education. 41(1). pp 55.

Sufean Hussin, Quek Ai Hwa, \& Loh Sau Cheong (2012). Policy into Practice: The Challenge for Special Education in Malaysia University of Malaya, Kuala Lumpur.

Sukbunpant, S., Arthur-Kelly, M., \& Dempsey, I. (2013). Thai preschool teachers' views about inclusive education for young children with disabilities. International Journal of Inclusive Education, 17(10), 1106-1118

Watson, N., Roulstone, A., \& Thomas, C. (Eds.). (2013). Routledge handbook of disability studies. London: Routledge.

Wood, S. J., Murdock, J. Y., \& Cronin, M. E. (2002). Self-Monitoring and At-Risk Middle School Students: Academic Performance Improves, Maintains, and Generalizes. Behavior Modification, 26(5), 605-626. 

copy, distribute, transmit or adapt the article content, providing a proper, prominent and unambiguous attribution to the authors in a manner that makes clear that the materials are being reused under permission of a Creative Commons License. Views, opinions and conclusions expressed in this research article are views, opinions and conclusions of the author(s). Open Access Publishing Group and European Journal of Special Education Research shall not be responsible or answerable for any loss, damage or liability caused in relation to/arising out of conflict of interests, copyright violations and inappropriate or inaccurate use of any kind content related or integrated on the research work. All the published works are meeting the Open Access Publishing requirements and can be freely accessed, shared, modified, distributed and used in educational, commercial and non-commercial purposes under a Creative Commons Attribution 4.0 International License (CC BY 4.0). 